$$
\text { "pehkonen" — 2005/7/1 — 13:22 — page } 13 \text { - \#1 }
$$

\title{
Comparative survey on pupils' beliefs of mathematics teaching in Finland and Ukraine
}

\author{
Erkki Pehkonen and Sergey Rakov
}

Abstract. The focus of this comparative survey was the following research question: What are the differences and similarities in pupils' beliefs in mathematics between Finland and Ukraine? Data were gathered with the help of a questionnaire. The questionnaire consists of 32 structured statements about mathematics teaching for which the pupils were asked to rate their beliefs on a 5-step scale. The Finnish sample comprised 255 pupils, and the Ukrainian sample 200 pupils. Our data has been gathered with a non-probabilistic convenience sampling.

The main results of our survey are, as follows: Generally, pupils' beliefs of mathematics teaching and learning in Finland and Ukraine are rather far from similar. An investigation of the differences between pupils' answers across the two countries also showed beliefs that are characteristic for each country. For pupils in Finland, the characteristic beliefs seem to be, as follows: the value of strict discipline, working in small groups, and the idea that all understand. For pupils in Ukraine, the most characteristic might be the following beliefs: the use of learning games, the emphases of mathematical concepts, and teachers' explanations.

Key words and phrases: mathematical beliefs, international comparison, mathematics teaching in Finland and Ukraine.

ZDM Subject Classification: B20.

\section{Introduction}

Analysis of similarities and differences in pupils' beliefs on mathematics teaching is interesting for discovering new effective methods for mathematics teaching

Copyright (C) 2005 by University of Debrecen 


$$
\text { "pehkonen" — 2005/7/1 — 13:22 — page } 14 \text { - \#2 }
$$

and learning. Comparison of pupils' beliefs on mathematics teaching in Finland and Ukraine is of special interest, because of only last years the opportunities for such work have arrived. Just in this moment comparative research may be the most interesting and productive - both parts of the world (east and west) were developed until the 1990's separately, competing in results and do not changing ideas.

A short outline for the structure of the paper: Firstly we will give a brief description of the current state of the mathematics education in Finland and in Ukraine. Secondly in the data analysis, we will give an overview of results with the help of consensus reached in answers, and an interpretation of obtained data. At the end, there are conclusions and some directions for further investigations.

On belief research in mathematics education

Within a constructivist framework (e.g. Davis \& al., 1990) as a base for teaching and learning mathematics, a knowledge of teachers' and pupils' mathematical beliefs is vital, if their mathematical behaviour is tried to be understood. Over the last decade, many studies of pupils' belief systems have been undertaken (cf. the overview of Op't Eynde \& al., 2002). An overview of pupils' mathematics-related beliefs, from a European viewpoint, was provided by Pehkonen (1995).

Research has revealed that knowing the right facts, that is, algorithms and procedures, does not necessarily guarantee success in solving mathematical problems. There are other factors - such as decisions a solver makes and strategies he uses, as well as his emotional state when solving mathematical tasks - that have a major effect on the solver's performance. "Purely cognitive" behaviour is rare. Belief systems shape cognition, even though all people may not be consciously aware of their beliefs (Schoenfeld, 1985).

\section{The concept: belief}

The importance of beliefs is earning more and more recognition in mathematics education, as already shown in the wide survey (Törner \& Pehkonen, 1996; Pehkonen \& Törner, 1999). There is no uniquely accepted, exact definition of what the term 'belief' means. This term is taken from natural language and thus carries a burden of personal meanings that the user wishes to give to it, as it is discussed e.g. in Furinghetti \& Pehkonen (2002). Different authors have given different characterizations of beliefs and the relation of these entities with other elements such as knowledge and conception (see Abelson, 1979; McLeod, 1992;
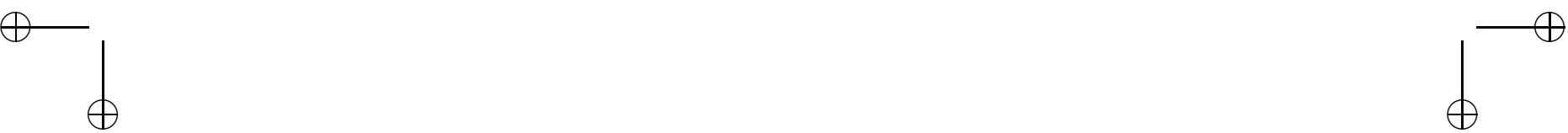


$$
\text { "pehkonen" — 2005/7/1 — 13:22 — page } 15 \text { - \#3 }
$$

Nespor, 1987; Pajares, 1992, Thompson, 1992). Schoenfeld (1992, 358) describes beliefs as "an individual's understandings and feelings that shape the ways that the individual conceptualizes and engages in mathematical behavior". This characterization has a very operative character, since it relates beliefs to behaviour, moreover it refers not only to cognitive components, but also to affective components. Our understanding of what a belief is may be further characterized by the following specification of its function in a system, as found in Pehkonen \& Törner (1996): (a) beliefs form a background regulating system of our perceptions, thinking, and actions, and therefore, (b) beliefs act as indicators for teaching and learning. Moreover, (c) beliefs can be seen as an inertia force that may work against change, and as a consequence (d) beliefs have a forecasting character.

Interest in beliefs and belief systems started mainly in the 1970s through developments in cognitive science. But the basis of these ideas was first developed in social psychology. Although beliefs are popular as a topic for study, the theoretical concept of belief has not been dealt with thoroughly. The main difficulty has been an inability to distinguish between beliefs and knowledge. This difficulty has not yet been clarified (e.g. Thompson, 1992). The notion of a belief system is a metaphor used to describe how one's beliefs are organized (Green, 1971).

Beliefs and belief systems are affected by the way people understand themselves and their surroundings. Today we see that belief systems are developed from simple perceptual beliefs or beliefs based on authority - via new beliefs, expectations, conceptions, opinions, and convictions - to a general understanding of life (cf. Saari, 1983). Thus, for example, conceptions are higher order beliefs. They are based on reasoning processes for which the premises are conscious. Therefore, conceptions can be seen to have grounds; they are justified and accepted at least for the person himself.

\section{Results of an International Comparison}

The question of the international comparison of pupils' mathematical beliefs seems to be a less explored field. The main question here is, as follows: "Are there essential differences in conceptions of mathematics teaching in different countries?" We know that mathematics can be understood as a universal discipline. So, the question arises as to whether pupils' conceptions of mathematics and of mathematics teaching and learning are also universal, or whether they are perhaps culture bound. 


$$
\text { "pehkonen" — 2005/7/1 — 13:22 — page } 16 \text { - \#4 }
$$

About ten years ago, a project entitled International Comparison of Pupils' Mathematics-Related Conceptions was started (cf. Pehkonen, 1995). Some results are published in international journals, as Pehkonen \& Safuanov (1996), and Furinghetti \& Pehkonen (2000). Prior to this project, from which some preliminary results have been published (e.g. Graumann \& Pehkonen, 1993; Pehkonen \& Tompa, 1994), there was almost no research into variations between pupils' beliefs on an international scale. Only in the International Mathematics Studies (e.g. Kifer \& Robitaille, 1989) and in the recently administered PISA study (e.g. Välijärvi \& al. 2002) were pupils' responses to some questions on the affective domain dealt with in a background questionnaire. Both the SIMS study and the PISA study indicated that there are large differences between countries on measures of mathematical beliefs and attitudes.

\section{Mathematics education system in both countries}

The comparison on the education systems in mathematics in both countries is written in a compressed style and is based on the following raster: description of the dominant school system, curricula development, respect for mathematics (i.e. teachers' position), learning results, equipment in schools.

\section{Finland}

Respect for mathematics is not very high in Finland. For example, teachers do not earn as much as other persons with the same academic degree; one could say that teachers belong to the "academic middle class". In addition, insufficient numbers of students at universities are willing to enroll in the mathematics teacher education program.

The strong points of the curriculum (Anon., 1994) are the objectives; they are really good. They include, in addition to numeracy, the promotion of problemsolving skills and the fostering of creativity, as well as applying mathematics in everyday life and developing positive attitudes. Furthermore, the teacher has considerable independence in his or her teaching, for example, in choosing how to teach, what content to emphasize, and in what order. Thus, an independent teacher with insight who is not merely following the textbook has an opportunity to teach in as "modern" a fashion as he or she likes. But unfortunately, most teachers are very textbook dependent.

The weak points in the mathematics curriculum are, as follows: All pupils are to be taught in heterogeneous classes throughout the compulsory grades (Grades 


$$
\text { "pehkonen" — 2005/7/1 — 13:22 — page } 17 \text { — \#5 }
$$

1-9; ages 7-15). In other words, in a ninth-grade mathematics class, you could have, at the same time, a future mathematics professor and some pupils who are not yet able to remember (and use) their multiplication tables. And the teacher is to try to teach them all according to their abilities. The current syllabus is mostly concerned with abstract and theoretical mathematics, and it is the same for all pupils. At the same time, the number of mathematics lessons in the 9 -year comprehensive school is the lowest in Europe - perhaps the lowest in the world according to a Unesco (1986) report, e.g. about half of the number of lessons in Switzerland during nine first years of school.

The curriculum in force attempts to give equal opportunities to all. In recent years, the question of talented pupils has been raised. They need also some challenges, but in the curriculum there is no extra place for them. Help for the low-attainers are arranged through special instruction, for which there are certain resources in the curriculum. Classroom teaching is mostly mechanistic and hurried; teachers work under a continuous press of time. Pupils spend most of their time filling in workbooks or calculating mechanically solvable tasks in their notebooks. The textbooks are published in the pupils' native language (Finnish or Swedish). They emphasize training in performing calculations, and that extends to the upper grades (grades 7-9; ages 13-15). Hardly any written teaching material is available in Finnish other than textbooks. There is plenty of material available in other languages, but very few teachers use these materials - the language is a big obstacle. Most schools have enough overhead projectors, film projectors, television sets, and computers, but there are very few suitable films and very little computer software. Some learning games in computers are used in lower grades, as in grades 3-6.

The Finnish success in international comparison studies, as TIMSS and PISA, has caused abroad large interest in Finnish school system and teaching methods. It is very complicated to find an answer to all the enquiries concerning Finnish success. In a recent publication (Välijärvi \& al., 2002), the PISA researchers do suggest that Finnish good results are due to several factors that are additionally interrelated. Such factors have to do, at least, with comprehensive pedagogy, students' own interests and leisure activities, the structure of the education system, teacher education, school practices, and, finally, Finnish culture.

\section{Ukraine}

The dominant compulsory school is the comprehensive school that uses about $90 \%$ of the population. In addition, there are some special schools with advanced
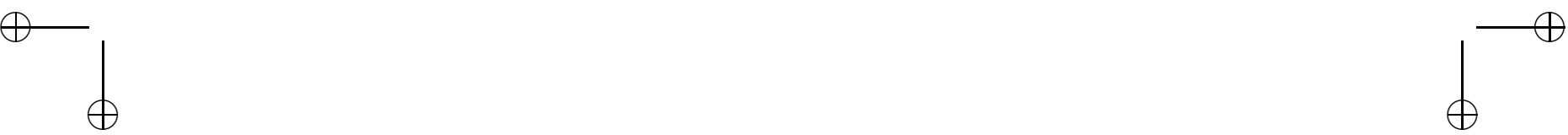


$$
\text { "pehkonen" — 2005/7/1 — 13:22 — page } 18 \text { - \#6 }
$$

mathematics programs, some private schools as well as university partner schools. In the description of mathematics teaching, we will restrict us to grammar school (grades 5-9, ages 10-15) in which our target pupils were during the administration of the questionnaire. Up to the grade 7 , all the schools has only one mathematics course which is named Mathematics, but from the grade 7 mathematics is divided into two courses: Geometry, and Algebra.

During grades 7-9, the depth of Mathematics courses differs from 3-5 hours per week. But in all these cases the general results of education have to be achieved. These compulsory results of education consist of two parts: abilities and practical skills, and examination papers for grade 9 are based on these.

Traditionally Mathematics education in Ukraine, as in the entire former USSR, was on rather high level, and its essentials were traditions of fundamentality. For example, the results in International Mathematics Olympiads and competitions, well-known popular literature, journal "Kvant" etc. Unfortunately the rating of mathematics in school has been falling down for last years. There are a lot of different reasons for it: the decrease of Sciences prestige in all New Independent States (NIS), Ukraine is nowadays rapidly changing its character from industrial military state to state with social-oriented economy, and therefore, mathematicians are not needed in previous proportion, the increasing role of the social and humanitarian professions in state life.

There are a lot of negative tendencies in state educational system: Joining classes up to 40 pupils in class. Forbidding division of classes into subgroups on laboratory works. Decreasing hours per week for Mathematics and sciences courses. Teaching is becoming more and more formal with tendency to simplify the theory, and drilling in solving typical tasks. As a consequence the mathematics culture of the school graduates is fallen down. Also teachers' salaries are very low even, in Ukrainian scale.

State schools are poorly equipped with computer classes - the majority of schools have now only one class on IBM compatible computers. There is very limited money for their maintenance and repairing, for buying educational software, paying for the teacher's training, payment for Internet services, etc.

The main problem of mathematics education in Ukraine on the author's mind is in this complicated process: how to save the traditions of high level fundamentality of mathematics curricula with enriching it with ideas of enquiry learning (including problem posing, problem solving, project work), pupil-centered education, collaborative methods of education, its practice orientation (real life problems solving) and fun.
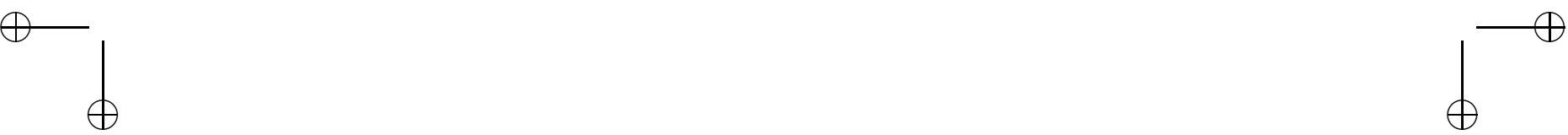


$$
\text { "pehkonen" — 2005/7/1 — 13:22 — page } 19-\# 7
$$

Comparative survey on pupils' beliefs of mathematics teaching in Finland and Ukraine

\section{Practical realization}

Since this study belongs to the first part of the pilot research within the research project "International Comparison of Pupils' Mathematical Beliefs" (cf. Pehkonen, 1995), data were gathered with the help of a questionnaire. The main question of the given research is, as follows: "What are the differences and similarities in pupils' beliefs between Finland and Ukraine in mathematics?"

\section{Questionnaire}

The needed data were gathered with the help of a questionnaire developed earlier for another project (cf. Pehkonen \& Zimmerman, 1990); later we refer to this questionnaire with a short name: PZ-questionnaire. The questionnaire consists of 32 direct statements that were answered by rating them in a scale from 1 to 5 ( 1 = fully agree, $\ldots, 5=$ fully disagree). In addition, the questionnaire is supplied with three open questions. An adequate impression on the questionnaire can be obtained from the appendix where all the 32 statements are given.

\section{Data gathering}

Finnish sample consists of 255 pupils from Helsinki and its suburb (Helsinki is the biggest city in Finland) in total 15 of 7 -grade classes. They were tested in 1990 at the end of mathematics lessons.

Ukrainian sample consists of 200 pupils from 6 of 7 -grade classes (including schools from Kharkov and its suburb (Kharkov is the second biggest city in Ukraine). Testing was arranged in the autumn of 1996 by the teachers of mathematics in a form of homework.

It should be noted that our sample is not trying to be a random sample with that one might generalize the results to the whole population. Using the language of Cohen \& Manion (1994), one may say that our data has been gathered with a non-probabilistic convenience sampling.

\section{Methods of data analysis}

To analyze the results of the questionnaire, the statistics used were mainly percentage tables. 


$$
\text { "pehkonen" — 2005/7/1 — 13:22 — page } 20 \text { - \#8 }
$$

The concept of consensus level

People differ in expressing their position regarding a statement: Some like to take an extreme position, whereas others tend to respond carefully. But usually their attitude (positive or negative) is clear. Therefore, for further analysis of the responses, we reduced the original response scale $(1-2-3-4-5)$ by combining the two response values at the extreme ends of the scale, which yields a three-step scale of agree (1 or 2 ), neutral (3), and disagree (4 or 5 ). This might in one hand dimish some of the tendencies in the data, but on the other hand it offers us a solid base to begin with.

In the analysis and interpretation of the responses, the terminology for the consensus level was used, as follows (cf. Pehkonen, 1993): We say that the responses to a statement are in

- complete consensus, if at least $95 \%$ of the test subjects' answers were at the same extreme end of the scale;

- consensus, if at least $85 \%$ but less than $95 \%$ of the test subjects' answers were at the same extreme end of the scale;

- almost consensus, if at least $75 \%$ but less than $85 \%$ of the test subjects' answers were at the same extreme end of the scale;

- lack of consensus, if less than $75 \%$ of the test subjects' answers were at either of the extreme ends of the scale.

The percentage of consensus, that is, the percentage of responses showing agreement $(1=$ completely agree or $2=$ agree $)$ or disagreement $(5=$ completely disagree or $4=$ disagree), is used to describe the consensus level of the test subjects' agreement (or disagreement) with a statement.

\section{Measuring the significance of differences}

Since the responses were on an ordinal scale, we used nonparametric statistics to test the statistical significance of differences between the countries. The Mann-Whitney $\mathrm{U}$ test used is equivalent to the ordinary (parametric) t-test on an interval scale. When using Mann-Whithey U test, we have stayed on the unreduced scale (5-point scale). This caused some pecularities, e.g. in item 4 which we will discuss later on. 


\section{Analysis of consensus levels in responses}

Firstly, the consensus percentages of the responses to the statements are analyzed. With the help of this analysis, we examine the main focus of the study: What differences did we find between the countries?

\section{An overview of results}

Table 1 gives following characteristics of the answer distributions on the PZquestionnaire in Finland and Ukraine. Explanations for different abbreviation in Table 1 are given in the following:

\begin{tabular}{|l|l|}
\hline$N$ & The number of an item in the PZ-questionnaire \\
\hline Question & A short description of an item (quotes) \\
\hline Mean (F) & The mean value of the Finnish answer distribution on a given item \\
\hline Mean (U) & The mean value of the Ukrainian answer distribution on a given item \\
\hline U-test & $\begin{array}{l}\text { The value of the statistical significance of differences of answer distrib- } \\
\text { utions on a given item between Finland and Ukraine according to the } \\
\text { Mann-Whitney U test }\end{array}$ \\
\hline Level & $\begin{array}{l}\text { Standard abbreviations for the statistical significance of differences of } \\
\text { answer distributions on a given item between Finland and Ukraine ac- } \\
\text { cording to the Mann-Whitney U test: } \\
* * * \text { means that the error is smaller than } 0.001 \text { (it lies in the interval } \\
] 0,0.001]) ; \\
* * \text { means that the error lies in the interval }] 0.001,0.01] ; \\
* \text { means that the error lies in the interval }] 0.01,0.05] ; \\
- \text { means that there is no statistically significant difference. }\end{array}$ \\
\hline
\end{tabular}

Table 1: Comparison of the mean values for the answers to the questionnaire items in Finland and Ukraine.

\begin{tabular}{|c|l|c|c|c|c|}
\hline$N$ & Statement & Mean(F) & Mean(U) & U-test & Level \\
\hline 1 & Doing calculations mentally & 1.76 & 1.74 & 0.8156 & - \\
\hline 2 & $\begin{array}{l}\text { Right answer . . more important than } \\
\text { the way }\end{array}$ & 3.60 & 3.56 & 0.6884 & - \\
\hline 3 & Mechanical calculations & 2.00 & 2.23 & 0.0104 & $*$ \\
\hline 4 & $\begin{array}{l}\text { Pupils can make questions, use trial } \\
\text { and error }\end{array}$ & 1.98 & 2.12 & 0.1108 & - \\
\hline 5 & $\begin{array}{l}\text { Everything should be expressed } \\
\text { exactly }\end{array}$ & 3.22 & 2.39 & 0.0001 & $* * *$ \\
\hline 6 & Drawing figures (e.g. triangles) & 2.31 & 1.76 & 0.0001 & $* * *$ \\
\hline 7 & To get the right answer very quickly & 3.71 & 2.92 & 0.0001 & $* * *$ \\
\hline
\end{tabular}




\begin{tabular}{|c|l|c|c|c|c|}
\hline 8 & Strict discipline & 1.51 & 2.22 & 0.0001 & $* * *$ \\
\hline 9 & Doing word problems & 2.20 & 1.89 & 0.0013 & $* *$ \\
\hline 10 & $\begin{array}{l}\text { There is . . procedure to exactly } \\
\text { follow }\end{array}$ & 3.07 & 2.59 & 0.0001 & $* * *$ \\
\hline 11 & All pupils understand & 1.85 & 3.31 & 0.0001 & $* * *$ \\
\hline 12 & Learn by memorizing rules & 3.30 & 3.92 & 0.0001 & $* * *$ \\
\hline 13 & Pupils put forward their own questions & 1.99 & 2.02 & 0.8264 & - \\
\hline 14 & Use of calculators & 2.04 & 2.46 & 0.0001 & $* * *$ \\
\hline 15 & Teacher help . . when . . difficulties & 2.04 & 2.22 & 0.0791 & - \\
\hline 16 & Everything should be reasoned exactly & 2.59 & 2.40 & 0.0641 & - \\
\hline 17 & $\begin{array}{l}\text { Different topics . . taught . . } \\
\text { separately }\end{array}$ & 2.77 & 2.72 & 0.6419 & - \\
\hline 18 & As much repetitions as possible & 2.45 & 2.32 & 0.1908 & - \\
\hline 19 & $\begin{array}{l}\text { Learning mathematics has practical } \\
\text { benefits }\end{array}$ & 1.52 & 1.91 & 0.0001 & $* * *$ \\
\hline 20 & Only . . talented pupils can solve & 4.27 & 3.29 & 0.0001 & $* * *$ \\
\hline 21 & $\begin{array}{l}\text { Learning mathematics is not always } \\
\text { fun }\end{array}$ & 2.46 & 2.44 & 0.8559 & - \\
\hline 22 & Calculations of areas and volumes & 2.09 & 2.09 & 0.9656 & - \\
\hline 23 & $\begin{array}{l}\text { Learning mathematics requires a lot of } \\
\text { efforts }\end{array}$ & 2.88 & 2.06 & 0.0001 & $* * *$ \\
\hline 24 & There is . . more than one way & 1.85 & 1.68 & 0.0215 & $* *$ \\
\hline 25 & Games can be used & 2.17 & 1.71 & 0.0001 & $* * *$ \\
\hline 26 & Teacher explains every stage exactly & 2.08 & 1.87 & 0.0298 & $*$ \\
\hline 27 & $\begin{array}{l}\text { Pupils are led to solve tasks } \\
\text { independently }\end{array}$ & 2.05 & 3.40 & 0.0001 & $* * *$ \\
\hline 28 & Construct of . . concrete objects & 2.91 & 2.37 & 0.0001 & $* * *$ \\
\hline 29 & As much practice as possible & 2.36 & 2.23 & 0.2745 & - \\
\hline 30 & $\begin{array}{l}\text { All or as much as possible is } \\
\text { understood }\end{array}$ & 1.86 & 2.16 & 0.0005 & $* *$ \\
\hline 31 & Working in a small group & 2.58 & 2.10 & 0.0001 & $* * *$ \\
\hline 32 & $\begin{array}{l}\text { Teacher . . tells . . exactly what ... } \\
\text { to do }\end{array}$ & & 0.2607 & - \\
\hline & & & & \\
\hline
\end{tabular}

Both researchers discussed the distribution of the items into the clusters so long that they found consensus in each item.

\footnotetext{
${ }^{1}$ Maybe pupils in compared countries understood strict discipline in different ways: the Ukrainians - as "punctuality" according to a tip, given in questionnaire; the Finns - as a general order in a class, controlled by the teacher, so it may be the nuance of correct translation.
} 


\section{Comparison of consensus levels in Finland and Ukraine}

Table 1 gives the general information about average opinion of pupils on questionnaire. It is obvious that the most fully information gives the distribution itself, but information in Table 2 complement Table 1 showing the level of belief polarization of pupils. Here the scale used has been contracted, as follows:

- agree (answers 1 and 2);

- neutral (answer 3);

- disagree (answers 4 and 5).

Table 2: Percentage of agreement-disagreement in Finland and Ukraine; the percentages over $75 \%$ are in bold font.

\begin{tabular}{|c|c|c|c|c|c|}
\hline$N$ & Statement & $\operatorname{Agree}(\mathrm{F})$ & $\operatorname{Disag}(\mathrm{F})$ & $\operatorname{Agree}(\mathrm{U})$ & $\operatorname{Disag}(\mathrm{U})$ \\
\hline 1 & Doing calculations mentally & 89 & 4 & 94 & 4 \\
\hline 2 & $\begin{array}{l}\text { Right answer ... more } \\
\text { important than the way }\end{array}$ & 16 & 40 & 22 & 71 \\
\hline 3 & Mechanical calculations & 77 & 5 & 72 & 15 \\
\hline 4 & $\begin{array}{l}\text { Pupils can make questions, use } \\
\text { trial and error }\end{array}$ & 78 & 4 & 71 & 9 \\
\hline 5 & $\begin{array}{l}\text { Everything should be expressed } \\
\text { exactly }\end{array}$ & 30 & 48 & 63 & 20 \\
\hline 6 & Drawing figures (e.g. triangles) & 66 & 14 & 84 & 9 \\
\hline 7 & $\begin{array}{l}\text { To get the right answer very } \\
\text { quickly }\end{array}$ & 11 & 68 & 42 & 41 \\
\hline 8 & Strict discipline & 90 & 2 & 69 & 17 \\
\hline 9 & Doing text problems & 76 & 17 & 84 & 4 \\
\hline 10 & $\begin{array}{l}\text { There is } \ldots \text { procedure to } \\
\text { exactly follow }\end{array}$ & 35 & 39 & 53 & 28 \\
\hline 11 & All pupils understand & 80 & 11 & 25 & 53 \\
\hline 12 & Learn by memorizing rules & 29 & 50 & 15 & 75 \\
\hline 13 & $\begin{array}{l}\text { Pupils put forward their own } \\
\text { questions }\end{array}$ & 76 & 10 & 81 & 4 \\
\hline 14 & Use of calculators & 72 & 8 & 58 & 24 \\
\hline 15 & $\begin{array}{l}\text { Teacher help ... when ... } \\
\text { difficulties }\end{array}$ & 76 & 15 & 65 & 20 \\
\hline 16 & $\begin{array}{l}\text { Everything should be reasoned } \\
\text { exactly }\end{array}$ & 52 & 24 & 58 & 15 \\
\hline 17 & $\begin{array}{l}\text { Different topics } \ldots \text { taught } \ldots \\
\text { separately }\end{array}$ & 36 & 23 & 47 & 29 \\
\hline 18 & As much repetitions as possible & 62 & 17 & 67 & 16 \\
\hline 19 & $\begin{array}{l}\text { Learning mathematics has } \\
\text { practical benefits }\end{array}$ & 94 & 6 & 77 & 23 \\
\hline
\end{tabular}




\begin{tabular}{|c|c|c|c|c|c|}
\hline 20 & $\begin{array}{l}\text { Only } \ldots \text { talented pupils can } \\
\text { solve }\end{array}$ & 5 & 84 & 30 & 55 \\
\hline 21 & $\begin{array}{l}\text { Learning mathematics is not } \\
\text { always fun }\end{array}$ & 61 & 20 & 66 & 18 \\
\hline 22 & $\begin{array}{l}\text { Calculations of areas and } \\
\text { volumes }\end{array}$ & 72 & 8 & 72 & 6 \\
\hline 23 & $\begin{array}{l}\text { Learning mathematics requires } \\
\text { a lot of efforts }\end{array}$ & 35 & 26 & 79 & 11 \\
\hline 24 & There is ... more than one way & 89 & 4 & 93 & 4 \\
\hline 25 & Games can be used & 66 & 10 & 88 & 5 \\
\hline 26 & $\begin{array}{l}\text { Teacher explains every stage } \\
\text { exactly }\end{array}$ & 72 & 13 & 81 & 10 \\
\hline 27 & $\begin{array}{l}\text { Pupils are led to solve tasks } \\
\text { independently }\end{array}$ & 73 & 8 & 22 & 58 \\
\hline 28 & $\begin{array}{l}\text { Construct of ... concrete } \\
\text { objects }\end{array}$ & 38 & 29 & 56 & 11 \\
\hline 29 & As much practice as possible & 63 & 11 & 70 & 14 \\
\hline 30 & $\begin{array}{l}\text { All or as much as possible is } \\
\text { understood }\end{array}$ & 75 & 4 & 80 & 8 \\
\hline 31 & Working in a small group & 85 & 5 & 73 & 9 \\
\hline 32 & $\begin{array}{l}\text { Teacher } \ldots \text { tells } \ldots \text { exactly } \\
\text { what } \ldots \text { to do }\end{array}$ & 52 & 29 & 71 & 14 \\
\hline
\end{tabular}

For more detailed analysis we list in Table 3 at first all the items on which both countries show consensus. It is worth while to mention that there are no item with double full agree (with percentage in both countries more then 85 percent), nor there are items with double disagree (which would mean consensus in the negative answer on an item).

Table 3: The statements with double consensus in Finland and Ukraine.

\begin{tabular}{|c|l|c|c|c|c|}
\hline$N$ & Statement & Agree(F) & Disag(F) & Agree(U) & Disag(U) \\
\hline 1 & Doing calculations mentally & 89 & 4 & 94 & 4 \\
\hline 24 & There is . m more than one way & 89 & 4 & 93 & 4 \\
\hline 19 & $\begin{array}{l}\text { Learning mathematics has } \\
\text { practical benefits }\end{array}$ & 94 & 6 & 77 & 23 \\
\hline 9 & Doing word problems & 76 & 17 & 84 & 4 \\
\hline 13 & $\begin{array}{l}\text { Pupils put forward their own } \\
\text { questions }\end{array}$ & 76 & 10 & 81 & 4 \\
\hline 30 & $\begin{array}{l}\text { All or as much as possible is } \\
\text { understood }\end{array}$ & 75 & 4 & 80 & 8 \\
\hline
\end{tabular}


Table 3 shows the joint part of the ideal model of a good teaching of mathematics in both countries: It must has practical benefits with doing word problems, pupils must have opportunities to pose their own questions, do calculations mentally and as a result understand as much as possible.

The next table (Table 4) show the separate consensus of Finnish pupils, obviously these could be interpreted as characteristic for Finland in comparison with Ukraine. The biggest differences are in answers to the questions 11 and 27; they could be interpreted in the following way: Maybe teaching in Finland is more democratic, informal, more pupil-centered, and in general - more constructive. Rather surprising is the full consensus in the eighth item, but we mentioned above (the earlier footnote) that it can be the result of different aspects in the meaning of strict discipline that was emphasized in Finnish and Ukrainian versions of the questionnaire. Additionally Finnish pupils prefer more to work in small groups, to believe not that mathematics is only for talented, to use trial-and-error methods, to put their own questions, to believe that when difficulties arise everybody could get the teacher's help and will understand the mathematics topic in question.

Table 4: The statements with separate consensus in Finland.

\begin{tabular}{|c|l|c|c|c|c|}
\hline$N$ & Statement & F-Agr & F-Disag & U-Agr & U-Disag \\
\hline 8 & Strict discipline & 90 & 2 & 69 & 17 \\
\hline 31 & Working in a small group & 85 & 5 & 73 & 9 \\
\hline 20 & Only . . talented pupils can solve & 5 & 84 & 30 & 55 \\
\hline 11 & All pupils understand & 80 & 11 & 25 & 53 \\
\hline 4 & $\begin{array}{l}\text { Pupils can make questions, use trial and } \\
\text { error }\end{array}$ & 78 & 4 & 71 & 9 \\
\hline 3 & Mechanical calculations & 77 & 5 & 72 & 15 \\
\hline 15 & Teacher help ... when ... difficulties & 76 & 15 & 65 & 20 \\
\hline
\end{tabular}

Table 5 shows the characteristic properties of the Ukrainian pupils. The greatest difference takes place in answers on the question 23: Thus according to Ukrainian pupils, mathematics learning take much more efforts than Finnish pupils are thinking. The Ukrainians hope more their teacher's explanations. The full consensus of the Ukrainian pupils in the case of learning games could be interpreted in two opposite ways: From one side, it may be a negative reaction to formal teacher-centered learning, and from the other side, it might be a conscious belief in the power of learning games that was developed with new innovative teaching methods. The right answer will need more careful investigations, tests, interviews, and additional questionnaires. The reaction to statement 6 could be interpreted as a demand of more practical benefits in mathematics teaching. 


$$
\text { "pehkonen" — 2005/7/1 — 13:22 — page } 26 \text { — \#14 }
$$

Table 5: The statements with separate consensus in Ukraine.

\begin{tabular}{|c|l|c|c|c|c|}
\hline$N$ & Statement & Agree(F) & Disag(F) & Agree(U)) & Disag(U) \\
\hline 25 & Games can be used & 66 & 10 & 88 & 5 \\
\hline 6 & Drawing figures (e.g. triangles) & 66 & 14 & 84 & 9 \\
\hline 26 & $\begin{array}{l}\text { Teacher explains every stage } \\
\text { exactly }\end{array}$ & 72 & 13 & 81 & 10 \\
\hline 23 & $\begin{array}{l}\text { Learning mathematics requires } \\
\text { a lot of efforts }\end{array}$ & 35 & 26 & 79 & 11 \\
\hline
\end{tabular}

\section{Additional points}

The next table (Table 6) completes the pupils' idea of good teaching of mathematics in both countries, but in a negative way. It lists the items where neither Finnish nor Ukrainian pupils have a consensus. Pupils in both countries have mixed beliefs in the following items, in the sense that some agreed and some disagreed with them. Therefore, we cannot say anything general on pupils' beliefs in these items.

The items in question are, as follows: Good mathematics teaching includes ... the idea that getting the right answer is always more important than the way of solving the problem ... the idea that everything ought to be expressed always as exactly as possible ... the idea that one ought to get always the right answer very quickly ... the idea that there is always some procedure which one ought to exactly follow in order to get the result ... the use of calculators ... the idea that everything will always be reasoned exactly ... the idea that different topics, such as calculation of percentages, geometry, algebra, will be taught and learned separately; they have nothing to do with each other ... the idea that there will be as much repetition as possible ... the idea that studying mathematics could not always be fun ... calculations of areas and volumes (e.g. the area of a rectangular and the volume of a cube) ... the idea that students are led to solve problems on their own without help from the teacher ... the constructing of different concrete objects (e.g. a box or a prism) and working with them ... the idea that there will be as much practice as possible ... the idea that the teacher always tells the students exactly what they ought to do. 


$$
\text { "pehkonen" — 2005/7/1 — 13:22 — page } 27 \text { — \#15 }
$$

Table 6: The list of statements with double lack of consensus (in both countries percentages of agreement and disagreement is less then 75).

\begin{tabular}{|c|l|c|c|c|c|}
\hline$N$ & Statement & \multicolumn{2}{|c|}{ FIN } & \multicolumn{2}{c|}{ UKR } \\
\hline & \multicolumn{1}{|c|}{ Agree } & Disagr & Agree & Disagr \\
\hline 2 & $\begin{array}{l}\text { Right answer . . more important than } \\
\text { the way }\end{array}$ & 16 & 40 & 22 & 71 \\
\hline 5 & Everything should be expressed exactly & 30 & 48 & 63 & 20 \\
\hline 7 & To get the right answer very quickly & 11 & 68 & 42 & 41 \\
\hline 10 & There is . . procedure to exactly follow & 35 & 39 & 53 & 28 \\
\hline 14 & Use of calculators & 72 & 8 & 58 & 24 \\
\hline 16 & Everything should be reasoned exactly & 52 & 24 & 58 & 15 \\
\hline 17 & Different topics . . taught . . separately & 36 & 23 & 47 & 29 \\
\hline 18 & As much repetitions as possible & 62 & 17 & 67 & 16 \\
\hline 21 & Learning mathematics is not always fun & 61 & 20 & 66 & 18 \\
\hline 22 & Calculations of areas and volumes & 72 & 8 & 72 & 6 \\
\hline 27 & $\begin{array}{l}\text { Pupils are led to solve tasks } \\
\text { independently }\end{array}$ & 73 & 8 & 22 & 58 \\
\hline 28 & Construct of ... concrete objects & 38 & 29 & 56 & 11 \\
\hline 29 & As much practice as possible & 63 & 11 & 70 & 14 \\
\hline 32 & $\begin{array}{l}\text { Teacher ... tells ... exactly what ... to } \\
\text { do }\end{array}$ & 52 & 29 & 71 & 14 \\
\hline
\end{tabular}

The last table (Table 7) shows the rating list of differences in answers between the Finnish and Ukrainian pupils in decreasing order of the absolute values. Data in this table could be interpreted in such a way that the pupils in Finland, more than in Ukraine, believes that good teaching and learning of mathematics is such that all pupils understand, and that pupils are led to solve problems on their own without help from the teacher. Whereas the Ukrainian pupils believe more than the Finnish ones that following points are elements of good mathematics teaching: Studying mathematics requires a lot of effort by pupils, and everything ought to be expressed always as exactly as possible.

Table 7: The rating list of differences in agreement percentages of answers in Finland and Ukraine (the difference is bigger than 20 units).

\begin{tabular}{|c|l|c|c|c|c|c|}
\hline$N$ & Statement & \multicolumn{2}{|c|}{ FIN } & \multicolumn{2}{c|}{ UKR } & \\
\hline & & Agree & Disagr & Agree & Disagr & Difference \\
\hline 11 & All pupils understand & 80 & 11 & 25 & 53 & 55 \\
\hline 27 & $\begin{array}{l}\text { Pupils are led to solve tasks } \\
\text { independently }\end{array}$ & 73 & 8 & 22 & 58 & 51 \\
\hline 23 & $\begin{array}{l}\text { Learning mathematics } \\
\text { requires a lot of efforts }\end{array}$ & 35 & 26 & 79 & 11 & -44 \\
\hline
\end{tabular}




\begin{tabular}{|c|l|c|c|c|c|c|}
\hline 5 & $\begin{array}{l}\text { Everything should be } \\
\text { expressed exactly }\end{array}$ & 30 & 48 & 63 & 20 & -33 \\
\hline 7 & $\begin{array}{l}\text { To get the right answer very } \\
\text { quickly }\end{array}$ & 11 & 68 & 42 & 41 & -31 \\
\hline 20 & $\begin{array}{l}\text { Only .. talented pupils can } \\
\text { solve }\end{array}$ & 5 & 84 & 30 & 55 & -25 \\
\hline 25 & Games can be used & 66 & 10 & 88 & 5 & -22 \\
\hline 6 & $\begin{array}{l}\text { Drawing figures (e.g. } \\
\text { triangles) }\end{array}$ & 66 & 14 & 84 & 9 & -22 \\
\hline 8 & Strict discipline & 90 & 2 & 69 & 17 & 21 \\
\hline
\end{tabular}

\section{Discussion}

Since the questionnaire is our only indicator, one should take a careful position toward our results. As a matter of fact, they are only results of a pilot study where the data was gathered with a convenience sampling, and not aiming to give any generalizable results. The questionnaire aims only at revealing interesting problems in an international comparison project (Pehkonen, 1995). And we did find some critical points that will open up new research questions.

\section{Summary of results}

Generally, pupils' beliefs of mathematics teaching and learning in Finland and Ukraine are rather far from similar. But we did find six items that had common responses in both countries, a so-called double consensus. The Mann-Whitney $\mathrm{U}$ test showed that for most items, the reactions of pupils in Finland and in Ukraine were not correlated. An investigation of the differences between pupils' answers across the two countries also showed beliefs that are characteristics for each country. For pupils in Finland, the characteristic beliefs for good teaching seem to be, as follows: strict discipline, working in small groups, and the idea that all understand. For pupils in Ukraine, the most characteristic might be the following beliefs: the use of learning games, the emphases of mathematical concepts, and teachers' explanations.

In addition, the study revealed some peculiarities in pupils' reactions in the two countries to the questions posed. For example, pupils in Ukraine were undecided in more items and in Finland. This fact might indicate low self-confidence 


$$
\text { "pehkonen" — 2005/7/1 — 13:22 — page } 29 \text { — \#17 }
$$

or lacking of meta-cognitive skills in the Ukrainian pupils that could be caused by an authoritarian style of teaching.

\section{Implications and conclusions}

The comparison shows that differences of pupils' beliefs on mathematics teaching in Finland and Ukraine are rather great. It reflects the fact that, possibly, these countries had belonged to two different worlds that were culturally isolated from each other for a long time. Naturally for this period these countries had different experiences, and therefore, their traditions and priorities in education and in particular in mathematical education differ. Nevertheless the comparison shows joint direction for improving mathematical education - it is the constructive approach against the formal and routine. Of course, the measures and ways of such improving are country-dependent.

In general, the comparison shows that beliefs of the Finnish pupils correspond more the ideas of pupil-centered constructive approach in mathematics education, according to the authors' opinion, than the Ukrainian ones. This conclusion arises an entire list of interesting research questions:

(1) What is a measure of "good" (adequate) beliefs on mathematics and mathematics teaching and learning? Naturally responses to this question depend on respondents' values. One possible way to continue is collect a group of specialists in mathematics education, and to ask their responses. For example, the experts who have used the PZ-test form a proper group, i.e. the mathematics educators involved in the project 'Pupils' beliefs on mathematical teaching".

(2) What kind of correlation between the pupils' beliefs on mathematical teaching and their mathematical performance are there? What is the measure of mathematical performance in different programs and curricula? Such a measure might be e.g. the Kassel-Exeter tests containing sub-tests in arithmetic, algebra, geometry, applied mathematics, and data processing (cf. Burghes \& Blum, 1995).

(3) What are productive ways for developing adequate pupils' beliefs on mathematics and mathematical teaching and learning? For example, what do we know on effectiveness of such popular and intensively discussed and investigated approaches as constructive approach, using open-ended problems in 
mathematics curricular, enquiry learning, project work etc.? Of course, answers on these questions lay deeper and are more general than the scope of the current paper.

(4) The scope can be enlarged from pupils' beliefs to those groups of persons who strongly influence pupils' beliefs. An interesting and important research area might be, as follows: "Beliefs (of pupils, students, teachers, mathematicians, parents) on mathematics and mathematics teaching" (cf. Pehkonen \& Törner, 1996). They together reflect the new stage on the way of democratization and humanization of the mankind in general and educational system in particular. No doubt that the results of such research will help mathematics teaching and learning become more interesting, pleasant and productive.

\section{Appendix}

1. Good mathematics teaching includes

doing calculations mentally

the idea that getting the right answer is always more important than the way of solving the problem

doing computations with paper and pencil

the idea that the student can sometimes make guesses and use trial and error the idea that everything ought to be expressed always as exactly as possible drawing figures (e.g. triangles)

the idea that one ought to get always the right answer very quickly

strict discipline

doing word problems

the idea that there is always some procedure which one ought to exactly follow in order to get the result

the idea that all students understand

the idea that much will be learned by memorizing rules

the idea that students can put forward their own questions and problems for the class to consider

the use of calculators

the idea that the teacher helps as soon as possible when there are difficulties the idea that everything will always be reasoned exactly

the idea that different topics, such as calculation of percentages, geometry, algebra, will be taught and learned separately; they have nothing to do with each other

the idea that there will be as much repetition as possible

the idea that studying mathematics has practical benefits

the idea that only the mathematically talented students can solve most of the 


$$
\text { "pehkonen" — 2005/7/1 — 13:22 — page } 31 \text { — \#19 }
$$

problems

the idea that studying mathematics could not always be fun

calculations of areas and volumes (e.g. the area of a rectangular and the volume

of a cube)

the idea that studying mathematics requires a lot of effort by students

the idea that there are usually more than one way to solve problems

the idea that games can be used to help students learn mathematics

the idea that when solving problems, the teacher explains every stage exactly

the idea that students are led to solve problems on their own without help

from the teacher

the constructing of different concrete objects (e.g. a box or a prism) and working with them

the idea that there will be as much practice as possible

the idea that all or as much as the student is capable of will be understood

the idea that also sometimes students are working in small groups

the idea that the teacher always tells the students exactly what they ought

to do

\section{References}

[1] R. Abelson, Differences between belief systems and knowledge systems, Cognitive Science 3 (1979), 355-366.

[2] Anon, Framework Curriculum for the Comprehensive School, National Board of Education, Helsinki: Painatuskeskus, 1994.

[3] D. Burghes and W. Blum, The Exeter-Kassel Comparative Project, A review of Year 1 and Year 2 Results, 1995, Proceedings of a Seminar on Mathematical Education, 27 February 1995, London.

[4] L. Cohen and L. Manion, Research Methods in Education, London: Routledge, 1994, (4th edition).

[5] R. B. Davis, C. A. Maher and N. Noddings (Eds.), Constructivist views on the teaching and learning of mathematics, JRME Monograph No. 4. Reston, VA: Council, 1990.

[6] F. Furinghetti and E. Pehkonen, Students' views of autonomy in their learning of mathematics: a comparative study, Nordic Studies in Mathematics Education 8 (4) (2000), 7-26.

[7] F. Furinghetti and E. Pehkonen, Rethinking Characterizations of Belief, In: Beliefs: A hidden variable in mathematics education?, (G. Leder, E. Pehkonen and G. Törner, eds.), Kluwer, Dordrecht, 2002, 39-57.

[8] G. Graumann and E. Pehkonen, Schülerauffassungen über Mathematikunterricht in Finnland und Deutschland im Vergleich, In: Beiträge zum Mathematikunterricht, (K. P. Müller, ed.), Verlag Franzbecker, Hildesheim, 1993, 144-147.

[9] T. F. Green, The activities of teaching, McGraw-Hill Kogakusha, Tokyo, 1971. 


$$
\text { "pehkonen" — 2005/7/1 — 13:22 — page } 32 \text { — \#20 }
$$

[10] E. Kifer and D. F. Robitaille, Attitudes, preferences and opinions, In: The IEA Study of Mathematics II: Contexts and outcomes of school mathematics, (D. F. Robitaille and R. A. Garden, eds.), Pergamon Press, Oxford, 1989, 178-208.

[11] D. B. McLeod, Research on Affect in Mathematics Education: A Reconceptualization, In: Handbook of research on mathematics learning and teaching, (D. A. Grouws, ed.), Macmillan,, New York, 1992, 575-596.

[12] J. Nespor, The role of beliefs in the practice of teaching, Journal of Curriculum Studies 19 (1987), 317-328.

[13] P. Op't Eynde, E. De Corte and L. Verschaffel, Framing students' mathematics-related beliefs: A quest for conceptual clarity and a comprehensive categorization, In: Beliefs: A hidden variable in mathematics education?, (G. Leder, E. Pehkonen and G. Törner, eds.), Kluwer, Dordrecht, 2002, 13-37.

[14] M. F. Pajares, Teachers' beliefs and educational research: cleaning up a messy construct, Review of educational research 62 (1992), 307-332.

[15] E. Pehkonen, What are Finnish teacher educators' conceptions about the teaching of problem solving in mathematics?, European Journal for Teacher Education 16 (3) (1993), 237-256.

[16] E. Pehkonen, Pupils' view of mathematics: Initial report for an international comparison project, University of Helsinki, Department of Teacher Education, Research Report, no. 152 (1995).

[17] E. Pehkonen and I. Safuanov, Pupils' views of mathematics teaching in Finland and Tatarstan, Nordic Studies in Mathematics Education 4(4) (1996), 31-59.

[18] E. Pehkonen and K. Tompa, Pupils' conceptions about mathematics teaching in Finland and Hungary, International Journal of Mathematical Education in Science and Technology 25(2) (1994), 229-238.

[19] E. Pehkonen and G. Törner, Mathematical Beliefs and Different Aspects of Their Meaning, International Reviews on Mathematical Education (= ZDM) 28(4) (1996), 101-108.

[20] E. Pehkonen and G. Törner (eds.), Pre-Proceedings of Oberwolfach meeting 'Mathematical beliefs and their impact on teaching and learning of mathematics", Schriftenreihe des Fachbereichs Mathematik, Gerhard-Mercator-Universität Duisburg Gesamthochschule, Preprint Nr. 457, 1999.

[21] E. Pehkonen and B. Zimmermann, Probleemakentät matematiikan opetuksessa ja niiden yhteys opetuksen ja oppilaiden motivaation kehittämiseen, Osa 1: Teoreettinen tausta ja tutkimusasetelma [Problem fields in mathematics teaching and their connection to the development of teaching and pupils' motivation, Part 1: Theoretical background and research design], University of Helsinki, Department of Teacher Education, Research Report, no. 86 (1990).

[22] H. Saari, Koulusaavutusten affektiiviset oheissaavutukset, [Affective consequences of school achievement], University of Jyväskylä, Institute for Educational Research, Publication, no. 348 (1983).

[23] A. H. Schoenfeld, Mathematical problem solving, Academic Press, Orlando, FL, 1985. 


$$
\text { "pehkonen" — 2005/7/1 — 13:22 — page 33 — \#21 }
$$

[24] A. Schoenfeld, Learning to think mathematically: problem solving, metacognition and sense making in mathematics, In: Handbook of research on mathematics learning and teaching, (A. D. Grouws, ed.), Macmillan, New York, 1992, 334-370.

[25] A. G. Thompson, Teachers' beliefs and conceptions: A synthesis of the research, In: Handbook of research on mathematics learning and teaching, (A. D. Grouws, ed.), Macmillan, New York, 1992, 127-146.

[26] G. Törner and E. Pehkonen, 1996., Literature on mathematical beliefs, Schriftenreihe des Fachbereichs Mathematik, Universität Duisburg. Preprint Nr. 341.

[27] Unesco, The place of science and technology in school curriculum: A global survey, Paris: Author, 1986.

[28] J. Välijärvi, P. Linnakylä, P. Kupari, P. Reinikainen and I. Arffman, The Finnish Success in PISA - and some Reasons Behind it, Institute for Education Research. University of Jyväskylä, 2002.

ERKKI PEHKONEN

UNIVERSITY OF HELSINKI

FINLAND

E-mail: erkki.pehkonen@helsinki.fi

SERGEY RAKOV

KHARKOV PEDAGOGICAL UNIVERSITY

UKRAINE

E-mail: rakov_s@ukr.net

(Received September, 2004) 